\title{
Identification and Pathogenicity of Three Species of Pythium Newly Isolated from Diseased Wheat and Barley Just After Thawing in Japan
}

\author{
Takio Ichitani*, Susumu TaKamatsu** and D. J. Stamps***
}

\begin{abstract}
Three species of Pythium ( $P$. okanoganense, $P$. vanterpooii, $P$. volutum) were newly identified as pathogens of Pythium snow rot of wheat and barley in Japan. From the results on frequency of isolation and pathogenicity, it can be concluded that $P$. okonoganense is an important pathogen, like $P$. iwayamai and $P$. paddicum reported previously by other authors, but both $P$. vanterpoolii and $P$. volutum are minor.
\end{abstract}

(Received September 19, 1985)

Key words : Pythium spp., Pythium snow rot, wheat, barley.

\section{Introduction}

A snow rot of cereals caused by Pythium sp. was first reported in Japan ${ }^{5)}$. A Latin description of the fungus was then provided and it was named $P$. iwayamai $\mathrm{S}$. Ito ${ }^{3)}$. Besides this fungus, three additional Pythium spp. ( $P$. graminicola Subr., $P$. horinouchiense Hirane, $P$. paddicum Hirane) were described as causal organisms ${ }^{1)}$, but two other species remained unidentified as minor pathogens ${ }^{1)}$.

The Pythium snow rot in Japan is favored by high soil fertility, poor drainage and snow cover, and no effective control measures are available so far, especially when the snow cover remains for a long period.

This study was conducted to identify three species of Pythium, in addition to the above four species already identified ${ }^{1,3}$, which are associated with rotted winter wheat and barley plants under snow and to determine their role in Pythium snow rot. Part of this work has already been reported elsewhere ${ }^{2,12}$.

\section{Materials and Methods}

Collection and identification of the Pythium spp. Diseased wheat (Triticum aestivum L.) and barley (Hordeum vulgare L.) plants (1,285 plant samples) were collected from 157 dieferent fields in Fukui Prefecture between 1982 and 1984. A diseased leaf

\footnotetext{
* College of Agriculture, University of Osaka Prefecture, Sakai, Osaka 591, Japan 大阪府立大 学農学部

** Fukui Agricultural Experiment Station, Ryomachi, Fukui 910, Japan

福井県農業試験場

*** Commonwealth Mycological Institute, Kew, Surrey TW9 3AF, UK
} 
was cut into pieces $(5 \times 5 \mathrm{~mm})$ and some of these were disinfected by dipping into $80 \%$ ethanol for $1 \mathrm{sec}$, followed by surface sterilizing with sodium hypochlorite solution (available chlorine : $0.5 \%$ ) for $3 \mathrm{~min}$. Isolations were made on plain agar or Bacto-cornmeal agar (Bacto-CMA) after rinsing the leaf pieces 3 times in sterile distilled water and removing the excess water by filter papers. After 7 days incubation at 2-3 $\mathrm{C}$, hyphal tips were isolated, followed by subculturing on cornmeal agar (CMA; $20 \mathrm{~g}$ cornmeal, $15 \mathrm{~g}$ agar, 1,000 $\mathrm{ml}$ distilled water) at about $15 \mathrm{C}$.

Zoospores were induced by the method described by Waterhouse ${ }^{18)}$. Media used in taxonomic studies included Bacto-CMA supplemented or not with 5,000 ppm wheat germ oil (Japan Impex Co., Ltd., Tokyo), Bacto-lima bean agar and Schmitthenner's synthetic agar. Dimensions recorded for the different fungal structures were based on a minimum of 100 measurements. Identification was usually made by following the Keys of Plaats-Niterink ${ }^{9)}$ or Waterhouse ${ }^{18}$.

Temperature-growth relations of Pythium spp. in the authors' collection was determined as described by Middleton ${ }^{8}$.

Pathogenicity trials. Pathogenicity tests were performed by using essentially the same method as described previously ${ }^{11}$. Seeds of the snow endurance wheat cultivar: Nanbu komugi and the susceptible: Noorin No. 61 were submerged in $0.1 \% \mathrm{HgCl}_{2}$ solution for $30 \mathrm{~min}$, rinsed in running tap water for 1-2 $\mathrm{hr}$, then allowed to germinate in a moist chamber at $20 \mathrm{C}$ for 1 day. Thirty seedlings/cultivar were grown in a row in autoclaved sandy loam soil in a plastic box $(32 \times 25 \times 7 \mathrm{~cm})$ under glasshouse conditions, with two rows in the same box for different cultivars (Oct. 18-Nov. 5, 1983). Seedlings were fertilized once every 7-10 days by watering with $200-300 \mathrm{ml}$ of about $50 \%$ Knop's solution and used for the pathogenicity tests without a hardening treatment.

Pythium isolates (2-4/species) were grown on a wheat bran-sand mixture ( $2 \mathrm{~g}$ wheat bran, $100 \mathrm{~g}$ sand and $25 \mathrm{ml}$ distilled water autoclaved at $121 \mathrm{C}$ for $30 \mathrm{~min}$ ) at $15 \mathrm{C}$ for about 1 month. During incubation, the cultures were mixed thoroughly once to ensure uniform colonization of the medium, then used as an inoculum.

The leaves of seedlings at the 2-3 leaf stage were bent to contact with a thin layer of inoculum which had been applied previously onto the soil surface $\left(100 \mathrm{~g} / 800 \mathrm{~cm}^{2}\right)$ in the plastic box, then covered with a pad of wet absorbent cotton to stimulate snow cover. After putting the lid, the box with inoculated seedlings was removed to a reservoir in a cold room (0-1 C) to feed water through a hole at the bottom of the box and kept for 40 days in the dark, then returned to the glasshouse (Dec. 14, 1983). The cotton cover was removed and plants were watered once with Knop's solution (200-300 ml/ box) to facilitate recovery. The number of surviving plants was recorded after the 10day recovery period. The same experiments were also performed using 2 barley cultivars : Benkei mugi and Miyuki ōmugi.

Experiments were repeated several times.

\section{Results}

Identification of Pythium spp.

1. Pythium okanoganense Lipps (Plate I, Figs. 1-5) 
Sporangia terminal, rarely intercalary, globose, subglobose or ovoid (Fig. 1), rarely pyriform (Fig. 2), infrequently proliferating (Fig. 3), 21-32 (mean 26) $\mu \mathrm{m}$ diam., sometimes borne in sympodial succession. Oogonia subglobose, smooth, sometimes with 1 , rarely 2 projections, terminal on generally short lateral branches, sometimes bearing short lateral hyphal elements, rarely becoming intercalary after continued outgrowth of a hypha, 19-28 (mean 24) $\mu \mathrm{m}$ diam. Oogonial wall rather unequal in thickness. Antheridia usually 1 , sometimes up to 4 per oogonium, making apical blunt contact with the oogonium, antheridial stalks slightly swollen, of monoclinous (Fig. 4) or occasionally diclinous origin at a distance of 3-20 $\mu \mathrm{m}$, sometimes bearing short lateral hyphal elements. Oospores aplerotic or almost plerotic, $15-22$ (mean 18) $\mu \mathrm{m}$, with a $1.1-2.5 \mu \mathrm{m}$ thick wall (Fig. 5).

Growth on CMA : min. below $0 \mathrm{C}$, opt. $22 \mathrm{C}$, max. below $30 \mathrm{C}$.

Isolates examined : UOP $2=\mathrm{CBS701.83,} \mathrm{IFO31941,} \mathrm{IMI280168;} \mathrm{UOP10}=$ IFO31921, IMI 280174 ; UOP14=IFO31922; UOP336 $=\mathrm{H}-82-72$.

Since sporangia of this fungus proliferate occasionally, this character can not be used for species separation among the species having proliferous sporangia such as $P$. middletonii, $P$. nagaii, $P$. polytylum and $P$. marsipium. However, the latter spp. can be readily distinguished from $P$. okanoganense by other morphologic features such as shape of sporangia, catenulate ooogonia, size of oogonium, number and origin of antheridia, and width of oospore walls".

$P$. irregulare, $P$. sylvaticum, $P$. ultimum var. sporangiiferum and $P$. vexans are species morphologically similar to $P$. okanoganense and having nonproliferous sporangia. However, an indeterminate number of projection and the size of sporangia of $P$. irregulare distinguish it from $P$. okanoganense. The latter differs from $P$. sylvaticum in having short, frequently inflated antheridial stalk, originating a short distance below the oogonium. The terminal and intercalary conidia common in $P$. sylvaticum are absent from $P$. okanoganense. Although apparently similar to $P$. okanoganense, $P$. ultimum differs in having monoclinous antheridia always originating immediately below the oogonium. The typically bell-shaped antheridial cells in $P$. vexans are never found ${ }^{9}$.

The three species ( $P$. graminicola, $P$. iwayamai, $P$. paddicum) reported by Hirane ${ }^{1)}$ clearly differ in such characters as shape of sporangia and ornamented oogonium. Although sex organs of $P$. horinouchiense are similar to those of $P$. okanoganense ${ }^{1}$, comparisons can not be made since no sporangia are described for the former.

The snow rot fungus agrees with $P$. okanoganense described by Lipps" in shape and size of sexual and asexual structures, infrequent proliferation of sporangia, forming sporangia in sympodial succession, aplerotic oospores, thick oospore wall and cardinal temperatures. Thus, this fungus was identified as $P$. okanoganense.

2. Pythium vanterpoolii V. Kouyeas \& H. Kouyeas (Plate I, Fig. 6; Plate II, Figs. 79)

Sporangia often consisting of catenulate complexes of subglobose bodies, terminal or intercalary (Figs. 6, 7). Oogonia smooth, globose, thin-walled, termial or intercalary, 1424 (mean 21) $\mu \mathrm{m}$ diam. Antheridia 1-2 per oogonium, club-shaped, monoclinous, rarely diclinous; antheridial stalks originating more than $10 \mu \mathrm{m}$ below the oogonium (Fig. 8), 
soon disappearing after fertilization (Fig. 9). Oospores plerotic, 13-21 (mean 20) $\mu \mathrm{m}$ diam., wall up to $4 \mu \mathrm{m}$ thick (Fig. 9).

Growth on CMA : min. about $0 \mathrm{C}$, opt. $25 \mathrm{C}$, max. 30-35 C.

Isolates examined : UOP3 $=\mathrm{IFO} 31923$, IMI280169; UOP $4=\mathrm{IFO} 31924, \mathrm{CBS} 700.83$, IMI 280170 ; UOP16=IFO31925, IMI280178; UOP337 = H-82-37 ; UOP338=H-82-40.

This fungus agreed in general with the description of $P$. torulosum ${ }^{9}$, but sporangia were asymmetrical, having frequently catenulate elements ${ }^{6)}$ as compared with the branched toruloid sporangial outgrowths of $P$. torulosum. Thus, this fungus was identified as $P$. vanterpoolii.

3. Pythium volutum Vanterpool \& Truscott (Plate II, Figs. 10-13)

Sporangia few, inflated with small lobes and toruloid outgrowths (Fig. 10). Oogonia smooth, globose, terminal on short side branches, occasionally intercalary, 20-41 (mean 28) $\mu \mathrm{m}$ diam. Antheridia terminal 1-6 per oogonium, clavate, crook-necked or straight, making apical contact, usually diclinous (Fig. 11), rarely monoclinous, the stalks frequently loosely entwining the oogonial stalk (Fig. 12). Oospores smooth, globose, plerotic, rarely aplerotic, 17-37 (mean 25) $\mu \mathrm{m}$ diam., wall variable, up to $3 \mu \mathrm{m}$ thick (Fig. 13).

Growth on CMA : min. about $0 \mathrm{C}$, opt. $25 \mathrm{C}$, max. $30 \mathrm{C}$.

Isolates examined : UOP5 $=\mathrm{CBS699} .83$, IFO31927, IMI280171; UOP18 $=$ IFO31926, IMI 280180 ; UOP39= IFO31928.

The fungus isolated is characterized by its diclinous long antheridial stalks which coil around the oogonial stalk and oogonium. $P$. helicum shows similar characters ${ }^{4}$ but may differ in having monoclinous antheridia. Although the predominantly plerotic oospores of the isolate differ slightly from those of $P$. volutum ${ }^{15)}$, the fungus may be identified as $P$. volutum, considering the similarity of the other main characters.

\section{Frequency of isolation}

Isolates of $P$. okanoganense, $P$. volutum and $P$. vanterpoolii comprised 7,6 and $4 \%$, respectively, of the total of all Pythium spp. detected in Fukui Prefecture. As shown in Table 1, these three species were isolated to an equally low extent regardless of the frequency of cropping. $P$. okanoganense and $P$. vanterpoolii were detected from barley much more frequently than from wheat, whereas $P$. volutum was isolated more often from wheat.

Table 1. Frequency of isolation of three species of Pythium from diseased wheat and barley leaves just after thawing a)

\begin{tabular}{|c|c|c|c|c|c|c|c|}
\hline \multirow{2}{*}{ Pythium spp. } & \multicolumn{3}{|c|}{ Wheat } & \multicolumn{3}{|c|}{ Barley } & \multirow{2}{*}{$\begin{array}{l}\text { The } \\
\text { sum } \\
\text { total }\end{array}$} \\
\hline & $\begin{array}{l}\text { l st } \\
\text { cropping }\end{array}$ & $\begin{array}{l}\text { Continuous } \\
\text { cropping }\end{array}$ & Total & $\begin{array}{l}\text { st } \\
\text { cropping }\end{array}$ & $\begin{array}{l}\text { Continuous } \\
\text { cropping }\end{array}$ & Total & \\
\hline No. of field surveyed & 37 & 10 & 47 & 85 & 25 & 110 & 157 \\
\hline No. of leaf pieces used & 245 & 209 & 454 & 621 & 210 & 831 & 1285 \\
\hline P. okanoganense & 2 & 0 & 2 & 21 & 2 & 23 & 25 \\
\hline$P$. vanterpoolii & 1 & 1 & 2 & 4 & 8 & 12 & 14 \\
\hline P. volutum & 2 & 13 & 15 & 1 & 5 & 6 & 21 \\
\hline Total & 5 & 14 & 19 & 26 & 15 & 41 & 60 \\
\hline
\end{tabular}

a) Isolated between 1982 and 1984 . 
Table 2. Pathogenicity of Pythium spp. to different cultivars of wheat

\begin{tabular}{|c|c|c|}
\hline Pythium spp. (Isolate no.)a) & Nanbu komugi & Norin No. 61 \\
\hline P. okanoganense (UOP 10) & $4 / 30^{b)}$ & $0 / 30$ \\
\hline$" \quad(" 336)$ & $2 / 30$ & $0 / 30$ \\
\hline P. vanterpoolii (UOP 3 ) & $30 / 30$ & $24 / 30$ \\
\hline " (" 16) & $24 / 30$ & $13 / 30$ \\
\hline$(" 337)$ & $29 / 30$ & $24 / 28$ \\
\hline$" \quad(" 338)$ & $29 / 30$ & $16 / 30$ \\
\hline P. volutum (UOP $\quad 5$ ) & $21 / 30$ & $0 / 30$ \\
\hline$"(" 39)$ & $27 / 30$ & $14 / 30$ \\
\hline Uninoculated 1 & $30 / 30$ & $30 / 30$ \\
\hline " 2 & $30 / 30$ & $30 / 30$ \\
\hline
\end{tabular}

a) UOP 10=IFO 31921, IMI 280174 ; UOP $3=$ IFO 31923, IMI 280169 ; UOP $16=$ IFO 31925 , IMI 280178 ; UOP $5=$ CBS 699.83 , IFO 31927 , IMI 280171 ; UOP $39=$ IFO 31928 .

b) Ratio of seedlings serviving to those inoculated.

\section{Pathogenicity}

Table 2 indicates that $P$. okanoganense was highly pathogenic on both cultivars of wheat, whereas $P$. volutum was less so and $P$. vanterpoolii was weakly or non-pathogenic. Similar results were obtained using 2 barley cultivars: Benkei mugi and Miyuki ömugi.

\section{Discussion}

$P$. okanoganense, $P$. vanterpoolii and $P$. volutum are newly identified in this paper as the causal fungi of Pythium snow rot of wheat and barley in Japan. Moreover, P. okanoganense and $P$. vanterpoolii are described for the first time in Japan (See Takahashi ${ }^{10)}$, Watanabe $\left.{ }^{17)}\right)$. Although 2 unidentified species have already been isolated by Hirane as a minor snow rot fungus"), comparisons can not be made between his species and ours since no sexual structures are described in the former. However, four species ( $P$. graminicola, $P$. horinouchiense, $P$. iwayamai, $P$. paddicum) identified by Hirane" differ from ours in several characters. $P$. graminicola has swollen filamentous sporangia, $P$. paddicum ornamented oogonia. Sporangia of $P$. iwayamai are spherical, ellipsoid, citriform or ovoid and usually papillate compared with the typical oblate-spheroidal and nonpapillate sporangia of $P$. okanoganense. Since the sporangia of $P$. vanterpoolii are asymmetrical, frequently with catenulate elements, this differs from any other fungus concerned. $P$. volutum is characterized by its diclinous, long antheridial stalks which coil around the oogonial stalk and oogonium.

For comparison, $P$. graminicola, $P$. iwayamai and $P$. paddicum were simultaneously isolated, together with several unidentified Pythium spp. $P$. iwayamai was detected most often (43\%), followed by $P$. paddicum (29\%), P. graminicola (7\%), P. okanoganense (7\%), $P$. volutum (69), P. vanterpoolii (4\%) and unidentified Pythium spp. (4\%). P. iwayamai was isolated most frequently from a field under continuous cropping, $P$. paddicum more often from a paddy field after the first wheat or barley crop. No clear differences in Pythium spp. and their frequency were found between wheat and barley. 
In pathogenicity tests for direct comparison with $P$. graminicola, $P$. iwayamai and $P$. paddicum, $P$. okanoganense was high pathogenic (90-100\% disease severity) like $P$. iwayamai (almost 100\%) and $P$. paddicum (90-100\%), but $P$. vanterpoolii and $P$. volutum were only weakly pathogenic (7-80\%). The facts that $P$. graminicola and $P$. volutum were highly pathogenic (80-90\%) on the wheat cultivar: Norin No. 61 but weakly pathogenic (20-40\%) on Nanbu komugi may due to a relatively higher resistance of the latter to snow damage. $P$. vanterpoolii was the weakest pathogen $(7-35 \%)$ among the Pythium isolates tested.

From the results on detection frequency and pathogenicity, it appears that $P$. graminicola, $P$. vanterpoolii and $P$. volutum are minor pathogen of Pythium snow rot of wheat and barley in Japan.

"Browning root rot" has been applied as a common name to the disease of wheat and barley under snow in Japan ${ }^{13}$. However, the authors prefer the more appropriate name "Pythium snow rot" to distinguish this disease from snow rot of wheat and barley caused by Typhula ishikariensis ${ }^{13)}$, and from symptoms of other Pythium root rots ${ }^{14,16)}$.

The authors are indebted to Prof. T. Inouye, University of Osaka Prefecture, for reading the manuscript.

\section{Literature cited}

1. Hirane, S. (1960). Trans. mycol. Soc. Japan $2: 82-87$ (In Japanese).

2. Ichitani, T., Takamatsu, S. and Stamps, D. J. (1984). Ann. Phytopath. Soc. Japan $50: 115$ (Abstr. in Japanese).

3. Ito, S. and Tokunaga, Y. (1935). Trans. Sapporo Nat. Hist. Soc. $14: 11-33$.

4. Ito, T. (1944). J. Jap. Bot. $20: 51-60$.

5. Iwayama, S. (1933). Agr. Exp. Sta., Toyama-Pref. Japan 1-20 (In Japanese).

6. Kouyeas, V. and Kouyeas, H. (1963). Ann. Inst. Phytopath. Benaki, N. S., 5:207-237.

7. Lipps, P. E. (1980). Mycologia $72: 1127-1133$.

8. Middleton, J. T. (1943). Mem. Torrey Bot. Club $20: 1-171$.

9. Plaats-Niterink, A. J. van der (1981). Stud. Mycol. $21: 1-242$.

10. Takahashi, M. (1970). Shokubutsu Bōeki (Plant Protection) 24:339-346 (In Japanese).

11. Takamatsu, S. (1983). Proc. Assoc. Pl. Prot. Hokuriku $31: 79-81$ (In Japanese).

12. Takamatsu, S. and Ichitani, T. (1983). Ann. Phytopath. Soc. Japan $49: 389$ (Abstr. in Japanese).

13. The Phytopathological Society of Japan (1975). Common Names of Economic Plant Diseases in Japan Vol. 1. The Phytopathological Society of Japan, Tokyo. pp. 19, 22. 26-27, 29 (In Japanese).

14. USDA (1960). Index of Plant Diseases in the United States. Agricultural Handbook No. 165. United States Department of Agriculture, Wash., D. C. pp. 187-188, 216.

15. Vanterpool, T. C. and Truscott. J.H.L. (1932). Can. J. Res. $6: 68-93$.

16. Waller, J. M. (1979). Pl. Path. $28: 17-24$.

17. Watanabe, T. (1984). Shokubutsu Bōeki (Plant Protection) $38: 203-211$ (In Japanese).

18. Waterhouse, G. M. (1967;. C.M.I. Mycol. Pap. 109:1-15.

\section{和 文 摘 要}

一谷多喜蚛・高松 進・D. J. STAMPS, ：融雪直後にオオムギおよびコムギの罹病葉から新たに分離された Pythium 菌 3 種の同定と病原性

哓にわが国で垠告のある 4 種のほかに，オオムギとコムギの褐色雪腐病菌として新たに 3 種を記載した。こ れらの菌の分激嚬度と病原性試験の結果から, P. okanoganense は P. iwayamai, P. paddicum 之同じように 重要な病原菌であるが, P. vanterpoolii とP. volutum は重要なあのではないと結論された。 


\section{Explanation of plates}

Plates I, II

Morphology of three species of Pythium identified.

All bars on the plates represent $20 \mu \mathrm{m}$.

Figs. 1-5. P. okanoganense

1. Zoospore release from spherical sporangium. 2. Pyriform sporangium. 3. Proliferating (arrow) sporangium. 4. Oogonium and monoclinous antheridium having slightly swollen (arrow) antheridial stalk. 5. Mature oospores with thick wall.

Figs. 6-9. P. vanterpoolii

6. Asymmetrical catenulate sporangia. 7. Empty sporangium with evacuation tube (arrow). 8. Oogonium and monoclinous antheridium. Antheridial stalk originating some distance (more than $10 \mu \mathrm{m}$ ) below the oogonium. 9. Oogonia without antheridia due to disappearing soon after fertilization, and plerotic, mature, thick-walled oospores.

Figs. 10-13. $P$. volutum

10. Empty sporangium (arrow). 11. Diclinous, crook-necked antheridia, making apical contact. 12. Antheridial stalks loosely entwining the oogonial stalk. 13. Plerotic oospores with relatively thin wall.

\section{Plate I}

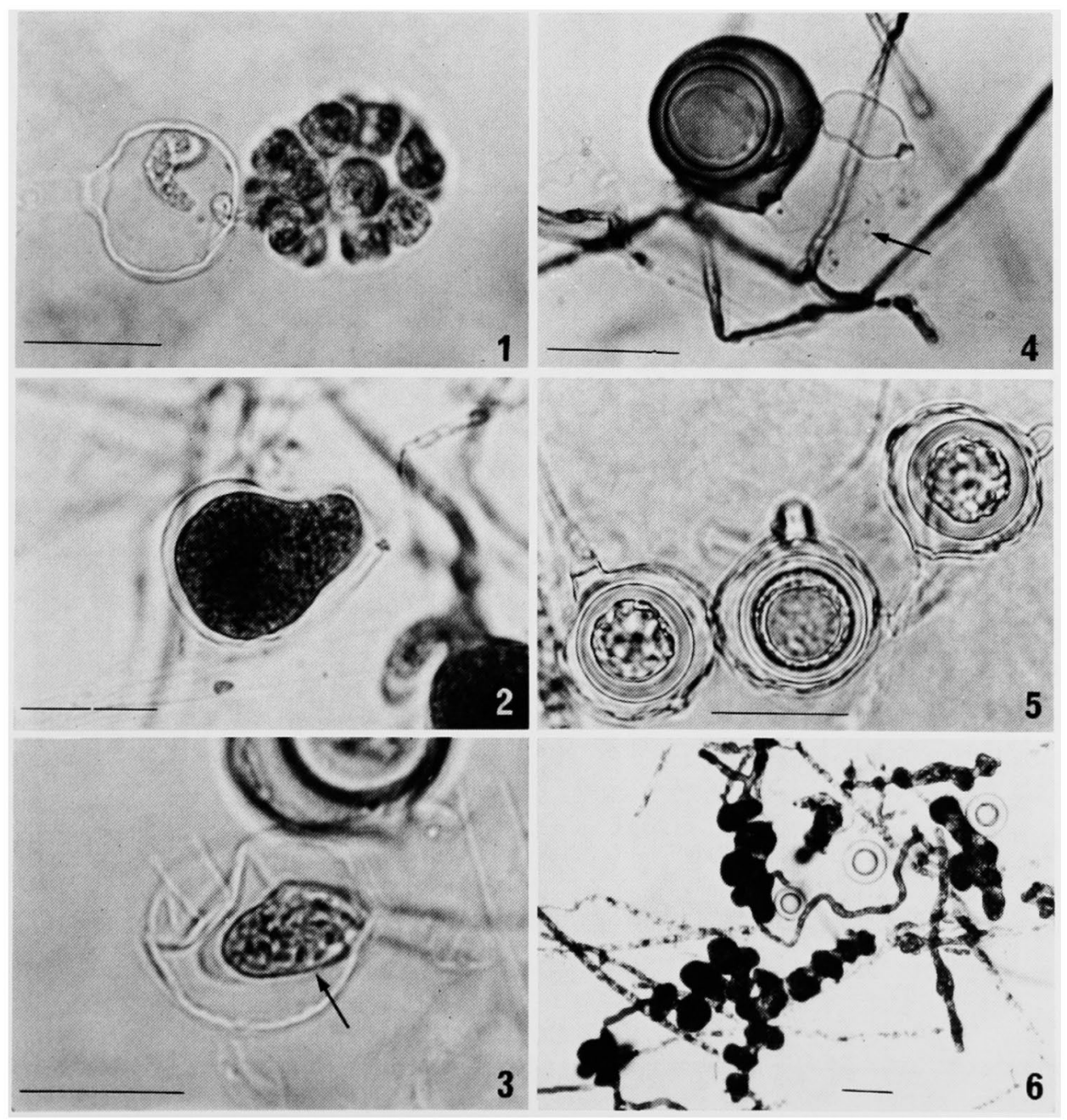




\section{Plate II}

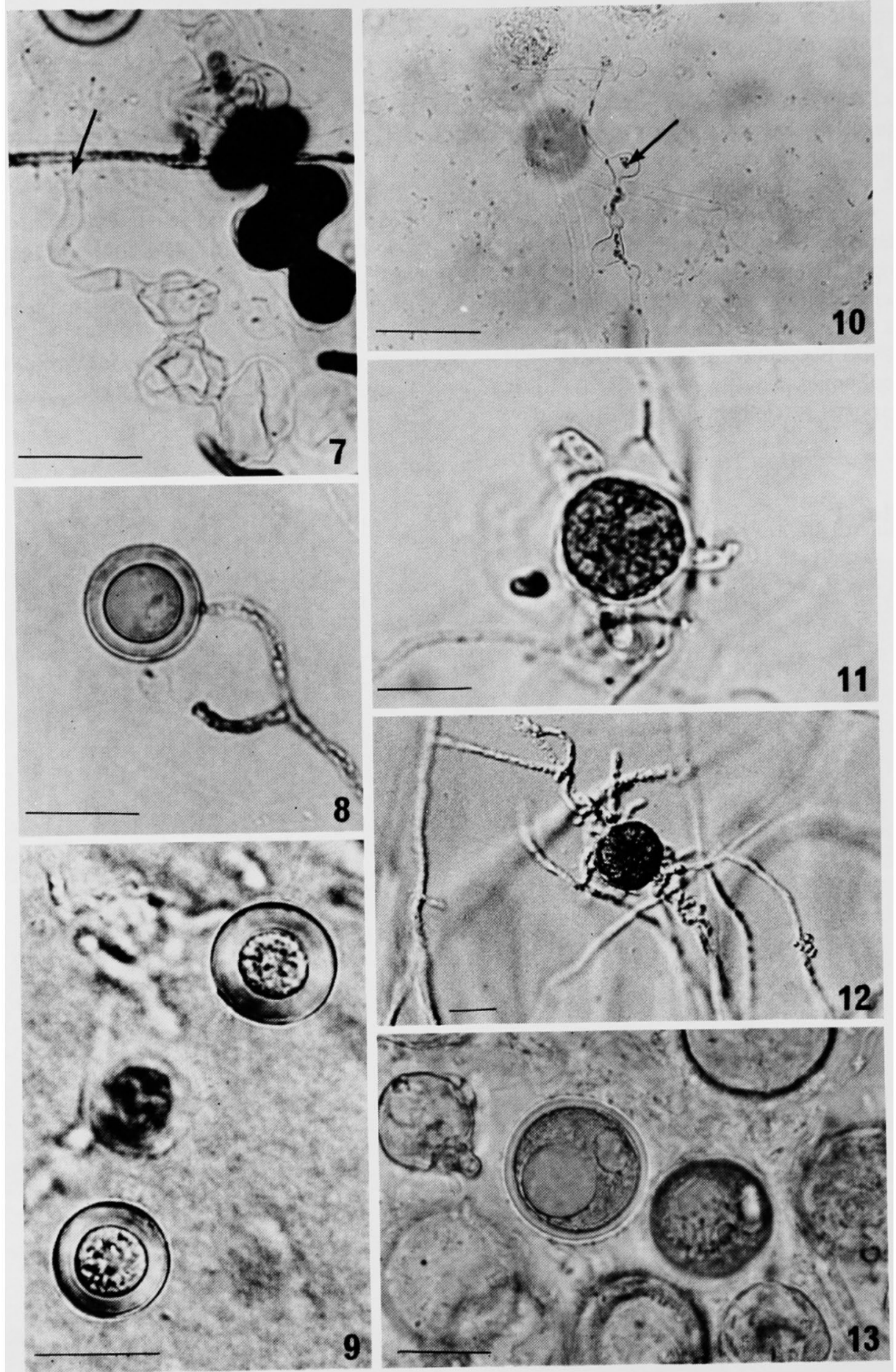

